\title{
Impact of Fall Armyworm (Lepidoptera: Noctuidae) in the Performance of Corn Crops Associated to Insecticides in Lowland Environment
}

\author{
Fabrício O. Fernandes ${ }^{1}$, Jéssica A. Abreu ${ }^{2}$, Lucas M. Christ ${ }^{2}$, Amilton F. da Silva ${ }^{3}$, Ana Paula S. A. da Rosa ${ }^{4}$, \\ Luis C. Belarmino ${ }^{5}$ \& José F. S. Martins ${ }^{4}$ \\ ${ }^{1}$ Department of Plant Protection, Paulista State University “Júlio de Mesquita Filho”, Jaboticabal, Brazil \\ ${ }^{2}$ Department of Plant Protection, Federal University of Pelotas, Pelotas, Brazil \\ ${ }^{3}$ Department of Agrarian Sciences, Federal University of São João Del-Rei, Sete Lagoas, Brazil \\ ${ }^{4}$ Department of Entomology, Embrapa Temperate Climate, Brazil \\ ${ }^{5}$ Department of Economics, Embrapa Temperate Climate, Brazil \\ Correspondence: Fabrício O. Fernandes, Department of Plant Protection, Paulista State University "Júlio de \\ Mesquita Filho", Jaboticabal, Brazil. ORCID: orcid.org/0000-0002-8776-8308. E-mail: fabriciof9@gmail.com
}

Received: August 24, 2019

doi:10.5539/jas.v11n18p155
Accepted: October 8, $2019 \quad$ Online Published: November 15, 2019

URL: https://doi.org/10.5539/jas.v11n18p155

\begin{abstract}
Brazil, in lowland environment, corn has the potential for crop rotation with irrigated rice to minimizing infestations of red rice. The use of resistant cultivars associated to the use of insecticides are the main methods of control of the fall armyworm, Spodoptera frugiperda (Smith, 1797) (Lepidoptera: Noctuidae). However, there are lack of field studies that assess the crop's production chain. The objective of this study was to evaluate the performance of corn cultivar, the conventional AG 9045 and the isogenic AG 9045 PRO2 Bt on the control of $S$. frugiperda, as well as to analyze the cost of production in the lowland environment. The cultivars were sown in the 2014/2015 and 2015/2016 harvests with adopted spacing of 0.7 meters and length of 5 meters. The application of insecticides was performed when the index of $10 \%$ of plants attacked by S. frugiperda was reached. Percentage (\%) of attacked plants, corn productivity $\left(\mathrm{kg} \mathrm{ha}^{-1}\right)$ and cost of production (US\$ ha $\left.{ }^{-1}\right)$ were evaluated. In the final analysis, the AG 9045 PRO2 isogenic Bt in conjunction to the chlorfenapyr + zeta-cypermethrin treatment show better efficiency on the control of $S$. frugiperda caterpillars, by a combination of two different control methods and active principles in the control of $S$. frugiperda, higher productivity indexes $\left(3,155.58 \mathrm{~kg} \mathrm{ha}^{-1}\right)$ and profitability $\left(-112.08{\mathrm{US} \$ \mathrm{ha}^{-1}}^{-1}\right)$.
\end{abstract}

Keywords: chemical control, varietal control, cultural management, productivity, production cost, biotechnology

\section{Introduction}

Brazil, although it is the world-renowned in the corn harvested area, presents low levels of productivity and profitability when compared to the world's largest producers, the United States and China (Trindade et al., 2017; CONAB, 2019).

Among the several factors that impair the performance of cultivars, insects are considered one of the most important. On the corn, Spodoptera frugiperda (Smith, 1797) (Lepidoptera: Noctuidae) known as fall armyworm attacks all the phases of the crop development (Cruz et al., 1999). The caterpillars, when young, feed by scraping the plant tissues and along of the development, go into of the cartridge causing severe damage (Campanha et al., 2012; Lima-Junior, 2012).

In Rio Grande do Sul state, in lowland environment, the corn is potentially one of the best alternatives for the crop rotation with irrigated rice because of the economic value it represents to the productive chain and being an alternative to minimize the high infestation rates of red rice (Porto et al., 1998; IRGA, 2019). The lowland areas dominate half of the state of Rio Grande do Sul, corresponding to 300 thousand hectares with significant increase in corn cultivation (Pinto, Miguel, \& Pauletto, 2017). 
The control of S. frugiperda on the corn crop has been carried out through chemical insecticides (Agrofit, 2019). However, inadequate product selection and incorrect equipment regulation have led to an increase in the number of applications and problems on the control of the target insect (Blanco et al., 2016; Pinto, Miguel, \& Pauletto, 2017).

The use of resistant cultivars is also an alternative on the control of the fall armyworm. In this context, the transgenic corn that is characterized by the insertion of one or more genes of the bacterium Bacillus thuringiensis (Berliner, 1915) (Bt) into corn genotypes induces the production of insecticidal proteins in high doses (Moraes, Lourenção, \& Paterniani, 2015; Bravo et al., 2017; Jurat-Fuentes, \& Crickmore, 2017). However, the continuous use of $B t$ corn for the control of $S$. frugiperda provides selection pressure and may favor the evolution of resistance (Omoto et al., 2016).

The resistance of $S$. frugiperda to $B t$ proteins expressed in corn has caused frequent failures on the pest control in the field. Storer et al. (2010) confirmed the existence of $S$. frugiperda populations resistant to Bt Cry1F corn in the region of Puerto Rico. The same was observed by Huang et al. (2014) in the Southeast region of the United States. In Brazil, faults were also observed on the control of $S$. frugiperda in several hybrids of $B t$ Cry1F corn (Farias et al., 2014). Due to this, the use of insecticides in Bt growing areas has increased considerably in all the corn producing regions. Therefore, the use of $B t$ corn and the association with insecticides became necessary for a satisfactory control of $S$. frugiperda (Blanco et al., 2016).

Nevertheless, with the adoption of several control methods, there is an increase in the production cost of the crop. Thus, the knowledge of this parameter can help producers to better adjust their investments and identify both the elements responsible for the good performance of the crop and the bottlenecks of the production process, helping this way the decision making (Richetti, 2017 ).

Due to the importance of the $S$. frugiperda represents to the corn crop, as well as the lack of field studies evaluating the behavior of the cultivars together with the use of insecticides, the objective of this study was to evaluate the performance of the cultivars corns, AG 9045 conventional and the AG 9045 PRO2 isogenic Bt on the control of S. frugiperda, as well to analyze the cost of production in lowland conditions.

\section{Materials and Methods}

\subsection{Characterization of the Area}

The sowing of corn in the field was performed on 11/29/2014 with emergency on 12/08/2014 (2014/2015 harvest) and 12/11/2015 with emergency on 12/18/2015 (2015/2016 harvest) at the Experimental Station of Embrapa Temperate Climate-RS, Brazil. The area presents alluvial hydromorphic soil, which is characterized as shallow, grayish, clayey texture and the presence of waterproof B horizon (Santos et al., 2013).

The seeds of the conventional corn cultivars AG 9045 and the AG 9045 PRO2 isogenic Bt expressing the Cry1A.105/Cry2Ab2 proteins were mechanically seeded (Tatu-T2SI model). In density of 75 thousand plants $\mathrm{ha}^{-1}$ (spacing of $0.7 \times 5 \mathrm{~m} \times 6$ lines) with 4 plots per treatment (Table 1). The irrigation system used was linear pivot driven according to the water requirement of the crop, evaluated daily.

\subsection{Chemical Control of S. frugiperda in Cultivars $A G 9045$ and $A G 9045$ Pro2}

The evaluations were carried out weekly in the plots, from the emergence of the seedlings. The chemical control was only adopted when $10 \%$ of the plants were attacked by S. frugiperda caterpillars (Hellwig et al., 2017). The infestation was calculated according to the formula:

$$
\text { Infestation }(\%)=(\mathrm{PA} \times 100) / \mathrm{PT}
$$

where, $\mathrm{PA}=$ Number of plants attacked; $\mathrm{PT}=$ Total number of plants in the evaluated row.

For the application of the insecticides (Table 1), 24 hours after field evaluation, $\mathrm{CO}^{2}$ pressurized costal spray (2.5 $\mathrm{kgf} \mathrm{cm}^{-2}$ ) was used. The equipment featured an application bar with fan-tip (Teejet XR $110.02 \mathrm{VS}$ ), calibrated at a volume of $200 \mathrm{~L} \mathrm{ha}^{-1}$. 
Table 1. Treatments used in the field experiment for the control of Spodoptera frugiperda in the 2014/2015 and 2015/2016 crop seasons

\begin{tabular}{|c|c|c|c|c|}
\hline \multirow{2}{*}{$\begin{array}{l}\text { Commercial name } \\
\text { Premio }^{\mathrm{TM}}\end{array}$} & \multirow{2}{*}{$\begin{array}{l}\text { Active ingredient } \\
\text { Chlorantraniliprole }\end{array}$} & \multirow{2}{*}{$\begin{array}{l}\text { Mechanism of action } \\
\text { Rannodyne receptor modulators }\end{array}$} & \multicolumn{2}{|c|}{ *Dose } \\
\hline & & & 100 & - \\
\hline Premio $^{\mathrm{TM}}+$ & Chlorantraniliprole + & Rannodyne receptor modulators + & 100 & 80 \\
\hline Mustang $^{(\mathbb{R}} 350 \mathrm{EC}$ & Zeta-Cypermethrin & Sodium channel modulators & & \\
\hline Belt $^{\circledR}$ & Flubendiamide & Rannodyne receptor modulators & 100 & - \\
\hline Belt $^{\circledR}+$ & Flubendiamide + & Rannodyne receptor modulators + & 100 & 80 \\
\hline Mustang $^{\circledR} 350 \mathrm{EC}$ & Zeta-Cypermethrin & Sodium channel modulators & & \\
\hline Pirate $^{\circledR}$ & Chlorfenapyr & De-couplers of oxidative phosphorylation via disruption of the proton gradient & 500 & - \\
\hline $\begin{array}{l}\text { Pirate }^{\circledR}+ \\
\text { Mustang }\end{array}$ & $\begin{array}{l}\text { Chlorfenapyr }+ \\
\text { Zeta-Cypermethrin }\end{array}$ & $\begin{array}{l}\text { De-couplers of oxidative phosphorylation via disruption of the proton gradient }+ \\
\text { Sodium channel modulators }\end{array}$ & 500 & 80 \\
\hline Mustang ${ }^{\circledR} 350 \mathrm{EC}$ & Zeta-Cypermethrin & Sodium channel modulators & 80 & - \\
\hline- & Witness & - & - & - \\
\hline
\end{tabular}

Note. ${ }^{*} \mathrm{~mL} \mathrm{ha}{ }^{-1}$.

\subsection{Experimental Design}

The experimental design was a completely randomized block, in a factorial scheme ( 2 cultivars $\times 8$ inseticides) with four replicates. By means of the Hartley test the data demonstrated heterogeneity in the variances, being transformed into arcsen $\sqrt{\mathrm{p} / 100}$. The data were submitted to analysis of variance and the means were compared by the Tukey test $(\mathrm{P}<0.05)$, paired analyzes were performed by Student's t-test. All analyzes were performed using the statistical program GENES (Cruz, 2019).

\subsection{Production Cost}

From the technical coefficients, for economic analysis, the partial budget method was applied, according to the formula for the processing of the economic analyzes from the reference data (Agrianual, 2019).

The standard cost of inputs and services in the implantation of the corn crop, conventional cultivars and $B t$ isogenic was used to the following formula:

$$
\mathrm{VF}=\mathrm{VU} \times \mathrm{Q}
$$

where, $\mathrm{VF}=$ final value; $\mathrm{VU}=$ unit value; $\mathrm{Q}=$ quantity used of each input or service.

The cost of production and the economic indexes were elaborated according to Scorvo-Filho, Martin, \& Ayroza (1998). The total cost per sack of $60 \mathrm{~kg}$ of corn, revenue (US\$ ha ${ }^{-1}$ ), average price (US\$ sc $60 \mathrm{~kg}$ ) and the corn profitability (US\$ ha ${ }^{-1}$ ) were calculated (Brazilian Central Bank, 2019).

\section{Results and Discussion}

\subsection{Chemical Control of S. frugiperda in Cultivars AG 9045 and AG 9045 Pro2}

In the 2014/2015 crop season to the cultivar, chemical control and their interaction, did not present significant difference in the vegetative stage V.3, V.5 and V.7 of the corn. Throughout the development of the seedlings, the cultivar factor responded significantly in the stages V.9, V.10 and VT to the attack of fall armyworm. In the chemical control parameter, differences were noted only in stage V.9, and not being verified interaction between the factors in subsequent evaluations (Table 2).

Therefore, due to the field conditions, it was observed that the intensity of the damage caused by the feeding of the insect was higher in the conventional cultivar than the isogenic $B t$. In the results obtained in the 2008/2009 crop season, variability was observed in the protection level of the $B t$ plants against the attack of the fall armyworm. Plants with genes that contained insecticidal properties protected at least three applications of the insecticides in conventional cultivars (Carneiro et al., 2009; Bravo et al., 2017). 
Table 2. Summary of the variance analysis of the chemical control of Spodoptera frugiperda in the corn crop (2014/2015 crop season)

\begin{tabular}{|c|c|c|c|c|c|c|c|}
\hline Sources of Variation & DF & $\begin{array}{l}28 / 12 / 2014 \\
\text { V.3 }\end{array}$ & $\begin{array}{l}13 / 01 / 2015 \\
\text { V.5 }\end{array}$ & $\begin{array}{l}23 / 01 / 2015 \\
\text { V.7 }\end{array}$ & $\begin{array}{l}29 / 01 / 2015 \\
\text { V.9 }\end{array}$ & $\begin{array}{l}05 / 02 / 2015 \\
\text { V.10 }\end{array}$ & $\begin{array}{l}11 / 02 / 2015 \\
\text { VT }\end{array}$ \\
\hline & & \multicolumn{6}{|c|}{ 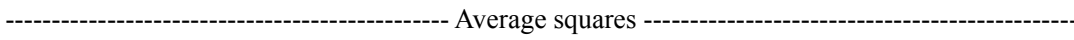 } \\
\hline Cultivar & 1 & $7.39^{\mathrm{ns}}$ & $94.60^{\mathrm{ns}}$ & $161.23^{\mathrm{ns}}$ & $1,147.85 *$ & $18,434.17 * *$ & $17,036.12 * *$ \\
\hline Chemical control & 7 & $1.50^{\mathrm{ns}}$ & $295.96^{\mathrm{ns}}$ & $250.18^{\mathrm{ns}}$ & $109.39^{\mathrm{ns}}$ & $599.47 *$ & $90.12^{\mathrm{ns}}$ \\
\hline Cultivar $\times$ Chemical control & 7 & $3.57^{\mathrm{ns}}$ & $108.23^{\mathrm{ns}}$ & $85.65^{\mathrm{ns}}$ & $313.34^{\mathrm{ns}}$ & $250.56^{\mathrm{ns}}$ & $92.47^{\mathrm{ns}}$ \\
\hline Block & 3 & 8.40 & 178.64 & 157.78 & 205.06 & 203.03 & 93.68 \\
\hline Residue & 45 & 2.00 & 48.83 & 105.52 & 253.55 & 437.41 & 507.58 \\
\hline Average & & 1.27 & 49.99 & 19.35 & 65.92 & 70.05 & 79.84 \\
\hline $\mathrm{CV} \%$ & & 98.09 & 26.74 & 64.91 & 21.72 & 20.34 & 12.12 \\
\hline
\end{tabular}

Note. $\mathrm{DF}=$ Degrees of freedom. $\mathrm{NS}=$ Not significant. $\mathrm{CV} \%=$ Coefficient of variation. $* 5 \%$ of probability by $\mathrm{F}$ test. $* * 1 \%$ of probability by $\mathrm{F}$ test. $\mathrm{V}=$ Vegetative stage. $\mathrm{VT}=$ reproductive stage.

The cultivars, both conventional and transgenic, showed similar behavior up to the stage V.7 of development, from that, the population of S. frugiperda in the cultivar AG 9045 had an increase of $33.99 \%$ (V.9) and 32. 63\% (VT) compared to the isogenic $B t$ (Table 3).

The results show that from $01 / 13 / 2015$ (V.5) the two cultivars, especially the conventional cultivar, reached the control level (10\% of the infested plants). To the conventional cultivar AG 9045 by not presented resistance genes to the fall armyworm, it was necessary to carry out 6 applications and for the isogenic Bt AG 9045 PRO2 it was necessary 5 applications of insecticides. In the field, it was also observed that the seedlings that had the $B t$ gene had less symptoms of scraped leaves and easily recovered themselves from the attack of the fall armyworm. Factor attributed to the genetic technology that contributes to insect-pest control (Mendes et al., 2011; Bravo et al., 2017).

In the 2011/2012 crop season, Shioga et al. (2012) reported high levels of infestation of the fall armyworm, with rates of $97.00 \%$ and $50.00 \%$ of attack in conventional and $B t$ isogenic cultivars, respectively, the same as in this study. The 2014/2015 crop season characterized a period of water stress, occurrence of diseases in corn, lodging and breakage caused by strong winds (Shioga et al., 2015; 2016).

The high incidence of the fall armyworm may be related to the instability of the climatic conditions that affected the recommended corn planting window. Another relevant factor is the nocturnal temperature that has reached higher means compared to the previous year, favoring the development and the increase of generations in the field (Wangen, Pereira-Junior, \& Santana, 2015; Viana, Faria, \& Bairros, 2016).

Table 3. Percentage of conventional corn plants AG 9045 and isolate Bt AG 9045 PRO2 attacked by Spodoptera frugiperda the field (2014/2015 crop season)

\begin{tabular}{lllllll}
\hline \multirow{2}{*}{ Cultivar } & $28 / 12 / 2014$ & $13 / 01 / 2015$ & $23 / 01 / 2015$ & $29 / 01 / 2015$ & $05 / 02 / 2015$ & $11 / 02 / 2015$ \\
& V.3 & V.5 & V.7 & V.9 & V.10 & VT \\
\hline AG 9045 & $2.34 \mathrm{a}^{1}$ & $51.21 \mathrm{a}$ & $66.49 \mathrm{a}$ & $70.16 \mathrm{a}$ & $87.02 \mathrm{a}$ & $96.16 \mathrm{a}$ \\
AG 9045 PRO2 & $1.32 \mathrm{a}$ & $48.77 \mathrm{a}$ & $63.32 \mathrm{a}$ & $61.69 \mathrm{~b}$ & $53.08 \mathrm{~b}$ & $63.53 \mathrm{~b}$
\end{tabular}

Note. ${ }^{1}$ Means followed by the same tiny letter in the column do not differ significantly from each other by the $\mathrm{T}$ test at the $5 \%$ probability level. $\mathrm{V}=$ Vegetative stage. $\mathrm{VT}=$ reproductive stage.

The percentage of plants attacked after the control of the fall armyworm, was only significant in the stage V.10, with the treatment chlorfenapyr + zeta-cypermethrin the lowest level of infestation, in relation to flubendiamide + zeta-cypermethrin and zeta-cypermethrin (Table 4). However, no treatments allowed an expressive reduction on the number of plants attacked, presenting a lower efficiency of $65.07 \%$ in insect-pest control.

With the adoption of the chemical control, there was no reduction in the insect-pest infestation at the non-action level, however, the performance involves several factors that influence the efficiency of chemical control. One possible factor involved is the active principle by itself and the difference between populations. Studies evaluating the control of $S$. frugiperda with chlorfenapyr showed different mortalities between the populations 
from Pelotas-RS (88.01\%) and Cascavel-PR (54.00\%) evidencing differences in susceptibility among populations (Gobbi et al., 2017).

Insecticides have often presented control failures, due in part to the increase of resistant individuals in the field, as a consequence of the spraying of insecticides with the same mechanism of action (Omoto et al., 2013).

The low efficiency in the control in the 2014/2015 crop season may also be related to the conditions of high rainfall that provided the product washing after application (Belay, Huckaba, \& Foster, 2012).

Table 4. Percentage of conventional corn plants AG 9045 and isogenic Bt AG 9045 PRO2 attacked by Spodoptera frugiperda in the field subjected to the chemical control (2014/2015 crop season)

\begin{tabular}{lllllll}
\hline \multirow{2}{*}{ Treatments } & $28 / 12 / 2014$ & $13 / 01 / 2015$ & $23 / 01 / 2015$ & $29 / 01 / 2015$ & $05 / 02 / 2015$ & $11 / 02 / 2015$ \\
& V.3 & V.5 & V.7 & V.9 & V.10 & VT \\
\hline Chlorantraniliprole & $0.00 \mathrm{a}^{1}$ & $52.75 \mathrm{a}$ & $63.70 \mathrm{a}$ & $69.90 \mathrm{a}$ & $72.22 \mathrm{ab}$ & $81.09 \mathrm{a}$ \\
Chlorantraniliprole + Zeta-Cypermethrin & $0.00 \mathrm{a}$ & $58.08 \mathrm{a}$ & $73.28 \mathrm{a}$ & $69.61 \mathrm{a}$ & $76.40 \mathrm{ab}$ & $82.93 \mathrm{a}$ \\
Flubendiamide & $0.00 \mathrm{a}$ & $56.27 \mathrm{a}$ & $56.33 \mathrm{a}$ & $58.92 \mathrm{a}$ & $62.68 \mathrm{ab}$ & $74.71 \mathrm{a}$ \\
Flubendiamide + Zeta-Cypermethrin & $0.83 \mathrm{a}$ & $53.17 \mathrm{a}$ & $71.34 \mathrm{a}$ & $67.76 \mathrm{a}$ & $78.18 \mathrm{a}$ & $81.19 \mathrm{a}$ \\
Chlorfenapyr & $0.34 \mathrm{a}$ & $48.02 \mathrm{a}$ & $64.43 \mathrm{a}$ & $68.13 \mathrm{a}$ & $65.20 \mathrm{ab}$ & $76.48 \mathrm{a}$ \\
Chlorfenapyr + Zeta-Cypermethrin & $1.49 \mathrm{a}$ & $43.08 \mathrm{a}$ & $66.06 \mathrm{a}$ & $64.90 \mathrm{a}$ & $53.77 \mathrm{~b}$ & $78.89 \mathrm{a}$ \\
Zeta-Cypermethrin & $1.05 \mathrm{a}$ & $47.35 \mathrm{a}$ & $64.74 \mathrm{a}$ & $64.81 \mathrm{a}$ & $76.49 \mathrm{a}$ & $78.51 \mathrm{a}$ \\
Witness & $1.01 \mathrm{a}$ & $41.18 \mathrm{a}$ & $59.35 \mathrm{a}$ & $63.32 \mathrm{a}$ & $75.42 \mathrm{ab}$ & $84.91 \mathrm{a}$ \\
\hline
\end{tabular}

Note. ${ }^{1}$ Means followed by the same tiny letter in the column do not differ significantly from each other by the Tukey test at the $5 \%$ probability level. $\mathrm{V}=$ Vegetative stage. $\mathrm{VT}=$ reproductive stage.

In the 2015/2016 crop season there was no significance in the stage V.3 to cultivars, products and the interaction between both. In the V.5 and V.10 stages, differences were observed for the cultivar, with effect on V.10 of the chemical control (Table 5).

Accordingly, to the crop development and favorable climatic conditions, there was an increase in the number of damages in both cultivars and crops. However, in the 2015/2016 crop season, the caterpillar pressure was lower, probably due to the fact that the population of $S$. frugiperda was reduced in the area due winter. With the emergence of the first adults from pupae that were in the area or from adults migrating from other regions, they oviposited and the caterpillars hatched, using crop leaf as food for development and future damage (Melo et al., 2014; Trindade et al., 2017).

Table 5. Overview of the variance analysis of the chemical control of Spodoptera frugiperda in the corn crop (2015/2016 Crop season)

\begin{tabular}{|c|c|c|c|c|c|c|}
\hline Sources of Variation & $\mathrm{DF}$ & $\begin{array}{l}12 / 01 / 2016 \\
\text { V.3 }\end{array}$ & $\begin{array}{l}18 / 01 / 2016 \\
\text { V.5 }\end{array}$ & $\begin{array}{l}03 / 02 / 2016 \\
\text { V.9 }\end{array}$ & $\begin{array}{l}11 / 02 / 2016 \\
\text { V.10 }\end{array}$ & $\begin{array}{l}16 / 02 / 2016 \\
\text { VT }\end{array}$ \\
\hline & & \multicolumn{5}{|c|}{ 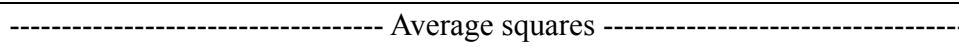 } \\
\hline Cultivar & 1 & $7.31^{\mathrm{ns}}$ & $89.67 * *$ & $0.34^{\mathrm{ns}}$ & $8,470.90 * *$ & $33.01^{\mathrm{ns}}$ \\
\hline Chemical control & 7 & $1.06^{\mathrm{ns}}$ & $155.60^{\mathrm{ns}}$ & $0.14^{\mathrm{ns}}$ & $235.22 * *$ & $7.52^{\mathrm{ns}}$ \\
\hline Cultivate $\times$ Chemical control & 7 & $4.59^{\mathrm{ns}}$ & $219.74^{\mathrm{ns}}$ & $0.14^{\mathrm{ns}}$ & $133.06^{\mathrm{ns}}$ & $16.22^{\mathrm{ns}}$ \\
\hline Block & 3 & 8.35 & 31.18 & 0.17 & 64.49 & 35.22 \\
\hline Residue & 45 & 2.73 & $21,657.53$ & 0.11 & 67.48 & 26.81 \\
\hline Average & & 1.20 & 34.08 & 0.07 & 23.50 & 4.21 \\
\hline $\mathrm{CV} \%$ & & 177.92 & 43.49 & 571.97 & 34.17 & 122.85 \\
\hline
\end{tabular}

Note. $\mathrm{DF}=$ Degrees of freedom. NS $=$ Not significant. CV\% $=$ Coefficient of variation. $* 5 \%$ of probability. $* * 1 \%$ of probability. $\mathrm{V}=$ Vegetative stage. $\mathrm{VT}=$ reproductive stage.

The percentages of attack of $S$. frugiperda had higher values in the cultivar AG 9045 in comparison to the isogenic $B t$ in all the vegetative stages and harvests (Table 6). The results are expected because of the conventional cultivar does not present genes that condition protection against the target insect. Another interesting factor is the early occurrence of the fall armyworm in the 2014/2015 crop season, possibly due to 
factors such as temperature, relative humidity and rainfall determined to the presence or absence of the insect (Waquil, Vilela, \& Foster, 2002).

In the regions of Campinas and Mococa, the results of damages caused by the fall armyworm, according to the Davis scale, were more severe in conventional crop cultivars P30F35, DKB 390 and DAS2B710 than in their transgenic versions at 60 days after the sowing of corn (Moraes, Lourenção, \& Paterniani, 2015). The cultivars AG 9010 and DKB 390 also presented lesions and holes in several leaves, whereas the Bt isogenic plants were verified with little damage in the region of Sete Lagoas-MG, Brazil (Mendes et al., 2008).

The increase of the percentage of the insect-pests was recorded to the phenological stage V.5 for both the 2014/2015 and 2015/2016 crops, 36 and 31 days after the emergence of the plants in the field, respectively. The phase characterizes the complete formation of the cartridge, associated to a period with favorable climatic conditions. This gives the crop a high susceptibility of the attack of the fall armyworm, lacking a constant monitoring (Polato \& Oliveira, 2011; Mendes et al., 2011).

Table 6. Percentage of conventional corn plants AG 9045 and isogenic Bt AG 9045 PRO2 attacked by Spodoptera frugiperda in the field (2015/2016 crop season)

\begin{tabular}{llllll}
\hline \multirow{2}{*}{ Cultivate } & $12 / 01 / 2016$ & $18 / 01 / 2016$ & $03 / 02 / 2016$ & $11 / 02 / 2016$ & $16 / 02 / 2016$ \\
& V.3 & V.5 & V.9 & V.10 & VT \\
\hline AG 9045 & $1.41 \mathrm{a}^{1}$ & $52.48 \mathrm{a}$ & $0.14 \mathrm{a}$ & $35.01 \mathrm{a}$ & $4.96 \mathrm{a}$ \\
AG 9045 PRO2 & $0.99 \mathrm{a}$ & $15.69 \mathrm{~b}$ & $0.00 \mathrm{a}$ & $11.99 \mathrm{~b}$ & $3.47 \mathrm{a}$ \\
\hline
\end{tabular}

Note. ${ }^{1}$ Means followed by the same tiny letter in the column do not differ significantly from each other by the $\mathrm{T}$ test at the $5 \%$ probability level. $\mathrm{V}=$ Vegetative stage. $\mathrm{VT}=$ reproductive stage.

The chemical control in the stage V.10 presented a significant difference between the treatments flubendiamide + zeta-cypermethrin (16.95\%) differing from the chlorantraniliprole (29.74\%) and witness (30.97\%) (Table 7). The efficiency of all treatments remained between $53.40 \%$ and $84.28 \%$, with three applications in the conventional cultivar AG 9045 and two applications in the isogenic Bt AG 9045 PRO2 throughout the crop cycle. In the 2014/2015 crop season, there was also a difference in the treatment, however, with a lower response to the efficiency of the control of the fall arwyworm caterpillar and a larger amount in the use of the chemical method.

Populations of S. frugiperda evaluated in Puerto Rico, submitted to the treatment with flubendiamide required a longer time ( $\geq 96$ hours) to achieve considerable levels of mortality. The fact is attributed to the resistance acquired due to the excessive use of the active principle that ends up selecting resistant individuals (Storer et al., 2010; Omoto, 2016).

The occurrence of $S$. frugiperda biotypes may be another limiting factor, since they may present different behaviors in relation to the susceptibility to insecticides (Pashley, Pawar, \& Bhatnagar, 1987; Adamczyk et al., 1997). Busato et al. (2006) evaluating $S$. frugiperda in the corn and rice crops, demonstrated that the $S$. frugiperda corn biotype was less susceptible to lambda-cyhalothrin, lufenuron and methoxifenozide insecticides.

Table 7. Percentage of the conventional corn plants AG 9045 and isogenic Bt AG 9045 PRO2 attacked by Spodoptera frugiperda in the field subjected to chemical control (2015/2016 crop season)

\begin{tabular}{llllll}
\hline Treatments & $12 / 01 / 2016$ & $18 / 01 / 2016$ & $03 / 02 / 2016$ & $11 / 02 / 2016$ & $16 / 02 / 2016$ \\
& V.3 & V.5 & V.9 & V.10 & $6.61 \mathrm{a}$ \\
\hline Chlorantraniliprole & $0.00 \mathrm{a}^{1}$ & $31.58 \mathrm{a}$ & $0.00 \mathrm{a}$ & $29.74 \mathrm{a}$ & $1.29 \mathrm{a}$ \\
Chlorantraniliprole + Zeta-Cypermethrin & $0.53 \mathrm{a}$ & $36.12 \mathrm{a}$ & $0.00 \mathrm{a}$ & $22.14 \mathrm{ab}$ & $3.48 \mathrm{a}$ \\
Flubendiamide & $0.00 \mathrm{a}$ & $36.07 \mathrm{a}$ & $0.29 \mathrm{a}$ & $19.51 \mathrm{ab}$ & $5.88 \mathrm{a}$ \\
Flubendiamide + Zeta-Cypermethrin & $1.53 \mathrm{a}$ & $31.18 \mathrm{a}$ & $0.00 \mathrm{a}$ & $16.95 \mathrm{~b}$ & $2.55 \mathrm{a}$ \\
Chlorfenapyr & $0.76 \mathrm{a}$ & $34.46 \mathrm{a}$ & $0.00 \mathrm{a}$ & $18.33 \mathrm{ab}$ & $3.47 \mathrm{a}$ \\
Chlorfenapyr + Zeta-Cypermethrin & $2.49 \mathrm{a}$ & $34.70 \mathrm{a}$ & $0.29 \mathrm{a}$ & $22.17 \mathrm{ab}$ & $6.93 \mathrm{a}$ \\
Zeta-Cypermethrin & $2.45 \mathrm{a}$ & $32.86 \mathrm{a}$ & $0.00 \mathrm{a}$ & $28.16 \mathrm{ab}$ & $3.48 \mathrm{a}$ \\
Witness & $1.86 \mathrm{a}$ & $35.67 \mathrm{a}$ & $0.00 \mathrm{a}$ & $30.97 \mathrm{a}$ & 3.45 \\
\hline
\end{tabular}

Note. ${ }^{1}$ Means followed by the same tiny letter in the column do not differ significantly from each other by the Tukey test at the $5 \%$ probability level. $\mathrm{V}=$ Vegetative stage. $\mathrm{VT}=$ reproductive stage. 
In the 2014/2015 crop season, it was not possible to perform a productivity evaluation ( $\mathrm{Kg} \mathrm{ha}^{-1}$ ), due to adverse climatic factors that prevented the harvest. However, in the 2015/2016 crop season, there was significance for the cultivar factor, with no effect of the products or interaction between the factors (Table 8).

Table 8. Overview of the variance analysis of the chemical control of Spodoptera frugiperda in the corn crop (2015/2016 harvest)

\begin{tabular}{lll}
\hline Sources of Variation & DF & Productivity \\
\hline Cultivate & 7 & $12,242,003.80 * *$ \\
Treatments & 7 & $427,573.58^{\mathrm{ns}}$ \\
Cultivate $\times$ Treatments & 3 & $167,109.92^{\mathrm{ns}}$ \\
Block & 1 & $253,959.79$ \\
Residue & 45 & $35,454.86$ \\
\hline Average & $2,718.12$ \\
\hline CV\% & 18.54 \\
\hline
\end{tabular}

Note. $\mathrm{DF}=$ Degrees of freedom. NS = Not significant. CV\% = Coefficient of variation. $* 5 \%$ of probability. $* * 1 \%$ of probability.

\subsection{Productivity}

The isogenic $B t$ AG 9045 PRO2 reached the highest value with 3,155.48 $\mathrm{kg} \mathrm{ha}^{-1}$, followed by the conventional one with 2,280.76 kg ha-1 (Table 9). The difference is attributed to the cultivar presenting $B t$ genes that provides less damage and interference on the photosynthetic capacity of the plant, responding significantly to grain yield (Moraes, Lourenção, \& Paterniani, 2015).

The low productivity reported in all treatments of the present work is attributed to the averages that the State presents from 1,413.18 to $5,457.61 \mathrm{Kg} \mathrm{ha}^{-1}$, however, climatic conditions may have influenced the development of the corn crop (SPGG, 2019).

Table 9. Productivity $\left(\mathrm{Kg} \mathrm{ha}^{-1}\right)$ between cultivars AG 9045 conventional and AG 9045 PRO2 isogenic $B t$ in the crop season 2015/2016

\begin{tabular}{ll}
\hline Cultivate & Productivity $\left(\mathrm{Kg} \mathrm{ha}^{-1}\right)$ \\
\hline AG 9045 & $2,280.76 \mathrm{~b}^{1}$ \\
AG 9045 PRO2 & $3,155.48 \mathrm{a}$
\end{tabular}

Note. ${ }^{1}$ Means followed by the same tiny letter in the column do not differ significantly from each other by the $\mathrm{T}$ test at the $5 \%$ probability level.

\subsection{Production Cost}

The profitability in the $2015 / 2016$ crop season, taking into account chemical control, was not observed. The result is direct interference in the grain yield. However, for the conventional and transgenic cultivars, chlorfenapyr + zeta-cypermethrin provided better control of the fall armyworm, contributing to better productivity index (Table 10).

The seed factor had a large participation on the final cost, representing a higher cost for AG9045 PRO2, representing an investment of $17.31 \%$ compared to the conventional seed. The same was observed on the conventional cultivars (2B604) and transgenic (2B604Hx) (Miguel et al., 2014). However, reductions of 10.00\% and $7.20 \%$ in operating costs were observed with the adoption of $B t$ technology (Miguel et al., 2013; Silva et al., 2015).

Thus, the implantation of transgenic corn meant a saving of $66.60 \%$ in comparison to the conventional one due to the reduction in the use of the chemical control. The use of the cultivar AG 9045 PRO2 contributed to the reduction of labor cost, fuel use, depreciation of agricultural machinery and even grain losses (Padilha et al., 2015; Richetti, 2017). 
Table 10. Economic evaluation of the corn crop (2015/2016 crop season)

\begin{tabular}{|c|c|c|c|}
\hline \multirow{2}{*}{ Treatments } & \multirow{2}{*}{ Parameters } & \multicolumn{2}{|c|}{ Technology } \\
\hline & & AG 9045 & AG 9045 PRO2 \\
\hline \multirow{5}{*}{ Chlorantraniliprole } & Total cost $\left(\mathrm{US} \$ \mathrm{ha}^{-1}\right)$ & $439.00^{1}$ & 513.65 \\
\hline & Total cost $\left(\mathrm{US} \$ \mathrm{sc}^{-1} 50 \mathrm{Kg}\right)$ & 11.26 & 9.90 \\
\hline & Revenue (US\$ ha ${ }^{-1}$ ) & 273.92 & 364.55 \\
\hline & Average price (US\$ sc ${ }^{-1} 50 \mathrm{~kg}$ ) & 7.03 & 7.03 \\
\hline & Profit (US\$ ha $\left.{ }^{-1}\right)$ & -187.53 & -149.10 \\
\hline \multirow{5}{*}{ Chlorantraniliprole + Zeta-Cypermethrin } & Total cost (US\$ ha $\left.{ }^{-1}\right)$ & 433.71 & 513.28 \\
\hline & Total cost $\left(\mathrm{US} \$ \mathrm{sc}^{-1} 50 \mathrm{Kg}\right)$ & 14.60 & 10.02 \\
\hline & Revenue (US\$ ha ${ }^{-1}$ ) & 208.83 & 360.04 \\
\hline & Average price $\left(\mathrm{US} \$ \mathrm{sc}^{-1} 50 \mathrm{~kg}\right)$ & 7.03 & 7.03 \\
\hline & Profit (US\$ ha ${ }^{-1}$ ) & -247.33 & -153.24 \\
\hline \multirow{5}{*}{ Flubendiamide } & Total cost (US\$ ha $\left.{ }^{-1}\right)$ & 437.49 & 513.31 \\
\hline & Total cost $\left(\mathrm{US} \$ \mathrm{sc}^{-1} 50 \mathrm{Kg}\right)$ & 12.05 & 10.02 \\
\hline & Revenue (US\$ ha-1) & 255.33 & 360.33 \\
\hline & Average price (US\$ sc ${ }^{-1} 50 \mathrm{~kg}$ ) & 7.03 & 7.03 \\
\hline & Profit (US\$ ha $\left.{ }^{-1}\right)$ & -204.60 & -152.97 \\
\hline \multirow{5}{*}{ Flubendiamide + Zeta-Cypermethrin } & Total cost (US\$ ha $\left.{ }^{-1}\right)$ & 441.45 & 512.72 \\
\hline & Total cost (US\$ sc $\left.{ }^{-1} 50 \mathrm{Kg}\right)$ & 10.21 & 10.21 \\
\hline & Revenue (US\$ ha ${ }^{-1}$ ) & 303.97 & 353.14 \\
\hline & Average price (US\$ sc ${ }^{-1} 50 \mathrm{~kg}$ ) & 7.03 & 7.03 \\
\hline & Profit (US\$ ha ${ }^{-1}$ ) & -159.92 & -159.58 \\
\hline \multirow{5}{*}{ Chlorfenapyr } & Total cost (US\$ ha $\left.{ }^{-1}\right)$ & 435.71 & 513.18 \\
\hline & Total cost $\left(\mathrm{US} \$ \mathrm{sc}^{-1} 50 \mathrm{Kg}\right)$ & 13.12 & 10.06 \\
\hline & Revenue (US\$ ha ${ }^{-1}$ ) & 233.43 & 358.74 \\
\hline & Average price $\left(\mathrm{US} \$ \mathrm{sc}^{-1} 50 \mathrm{~kg}\right)$ & 7.03 & 7.03 \\
\hline & Profit (US\$ ha ${ }^{-1}$ ) & -224.73 & -154.43 \\
\hline \multirow{5}{*}{ Chlorfenapyr + Zeta-Cypermethrin } & Total cost (US\$ ha $\left.{ }^{-1}\right)$ & 444.37 & 516.93 \\
\hline & Total cost $\left(\mathrm{US} \$ \mathrm{sc}^{-1} 50 \mathrm{Kg}\right)$ & 9.20 & 8.98 \\
\hline & Revenue (US\$ ha ${ }^{-1}$ ) & 339.80 & 404.84 \\
\hline & Average price (US\$ sc ${ }^{-1} 50 \mathrm{~kg}$ ) & 7.03 & 7.03 \\
\hline & Profit (US\$ ha ${ }^{-1}$ ) & -127.02 & -112.09 \\
\hline \multirow{5}{*}{ Zeta-Cypermethrin } & Total cost (US\$ ha ${ }^{-1}$ ) & 436.37 & 514.19 \\
\hline & Total cost $\left(\mathrm{US} \$ \mathrm{sc}^{-1} 50 \mathrm{Kg}\right)$ & 12.70 & 9.74 \\
\hline & Revenue (US\$ ha ${ }^{-1}$ ) & 241.56 & 371.29 \\
\hline & Average price (US\$ sc ${ }^{-1} 50 \mathrm{~kg}$ ) & 7.03 & 7.03 \\
\hline & Profit (US\$ ha-1) & -217.25 & -142.91 \\
\hline \multirow{5}{*}{ Witness } & Total cost (US\$ ha $\left.{ }^{-1}\right)$ & 413.57 & 502.88 \\
\hline & Total cost $\left(\mathrm{US} \$ \mathrm{sc}^{-1} 50 \mathrm{Kg}\right)$ & 10.34 & 9.18 \\
\hline & Revenue (US\$ ha ${ }^{-1}$ ) & 281.28 & 385.18 \\
\hline & Average price $\left(\mathrm{US} \$ \mathrm{sc}^{-1} 50 \mathrm{~kg}\right)$ & 7.03 & 7.03 \\
\hline & Profit (US\$ ha ${ }^{-1}$ ) & -154.73 & -117.69 \\
\hline
\end{tabular}

Note. ${ }^{1}$ Brazilian Central Bank-US\$ 0.2608 sale. Updated in April 10, 2019.

\section{Conclusion}

In the final analysis, the AG $9045 \mathrm{PRO} 2$ isogenic $B t$ in conjunction to the chlorfenapyr + zeta-cypermethrin treatment show better efficiency on the control of $S$. frugiperda caterpillars, by a combination of two different control methods and active principles in the control of $S$. frugiperda, higher productivity indexes $(3,155.58 \mathrm{~kg}$ $\mathrm{ha}^{-1}$ ) and profitability $\left(-112.08\right.$ US $\left.\$ \mathrm{ha}^{-1}\right)$. As such, this study did not consider natural enemies, whose 
interactions with the pest may negatively influence the pest population abundance from the adoption of conservative techniques. However, current results show the influence of different environmental factors on $S$. frugiperda population abundance, in particular, the month, condition of the plant, temperature and relative humidity, as the main drivers to $S$. frugiperda spatio-temporal population trends in lowland environment. This provides a significant step towards simple, localized $S$. frugiperda pest outbreak prediction to aid sustainable management.

\section{Acknowledgements}

We thank the Coordination of Improvement of Higher Education Personnel (CAPES), Paulista State University "Júlio de Mesquita Filho" and the Federal University of Pelotas for the grants of the grants and Embrapa Temperate Climate for the infrastructure granted. This study was financed in part by the Coordenação de Aperfeiçoamento de Pessoal de Nível Superior-Brasil (CAPES)-Finance Code 001.

\section{References}

Adamczyk, J. J., Holloway, J. W., Leonard, B. R., \& Graves, J. B. (1997). Susceptibility of fall armyworm collected from different plant hosts to selected insecticides and transgenic Bt cotton. Journal Cotton Science, $1,21-28$.

Agrianual. (2019). Anuário da Agricultura Brasileira (p. 482). São Paulo, Brazil.

Agrofit, Sistema de Agrotóxicos Fitossanitários. (2019). Retrieved April 11, 2019, from http://agrofit.agricultura. gov.br/primeira_pagina/extranet/AGROFIT.html

Belay, D. K., Huckaba, R. M., \& Foster, J. E. (2012). Susceptibility of the fall armyworm, Spodoptera frugiperda (Lepidoptera: Noctuidae), at Santa Isabel, Puerto Rico, to different insecticides. Florida Entomologist, 95, 476-478. https://doi.org/10.1653/024.095.0232

Blanco, C. A., Chiaravalle, W., Dalla-Rizza, M., Farias, J. R., García-Degano, M. F., Fastaminza, G., ... Willink, E. (2016). Current situation of pests targeted by Bt crops in Latin America. Current Opinion in Insect Science, 5, 131-138. https://doi.org/10.1016/j.cois.2016.04.012

Bravo, A., Pacheco, S., Gómez, I., Garcia-Gómez, B., Onofre, J., \& Soberón, M. (2017). Insecticidal proteins from Bacillus thuringiensis and their mechanism of action. In L. Fiuza, R. A. Polanczyk, \& N. Crickmore (Eds.), Bacillus thuringiensis and Lysinibacillus sphaericus (Vol. 1, pp. 41-52). Characterization and use in the field of biocontrol (1st ed.). Springer International Publishing, Berlim, Alemanha. https://doi.org/10.1007/ 978-3-319-56678-8_4

Brazilian Central Bank. (2019). Currency quote. Retrieved April 11, 2019, from https://www.bcb.gov.br

Busato, G. R., Grützmacher, A. D., Garcia, M. S., Zotti, M. J., Nörnberg, S. D., Magalhães, T. R., \& Magalhães, J. B. (2006). Susceptibilidade de lagartas dos biótipos milho e arroz de Spodoptera frugiperda (J.E. Smith, 1797) (Lepidoptera: Noctuidae) a inseticidas com diferentes modos de ação. Ciência Rural, 36, 15-20. https://doi.org/10.1590/S0103-84782006000100003

Campanha, M. M., Cruz, J. C., Resende, A. V., Coelho, A. M., Karam, D., Silva, G. H., ... Queiroz, V. A. V. (2012). Sistema de produção integrada de milho para Região Central de Minas Gerais (Relatório Destaques 2011-2013, p. 74). Sete Lagoas: Embrapa Milho e Sorgo.

Carneiro, A. A., Guimarães, C. T., Valicente, F. H., Waquil, J. M., Vasconselos, M. J. V., Carneiro, N. P., \& Mendes, S. M. (2009). Milho Bt: Teoria e Prática da Produção de Plantas Transgênicas Resistentes a Insetos-Praga (Circular Técnica 135, p. 26). Sete Lagoas: Embrapa Milho e Sorgo.

CONAB. (2019). Observatório agrícola: Acompanhamento da safra brasileira 2017/2018 (Grão) (No. 6, pp. 1-129). Brasília, Brazil.

Cruz, C. D. (2019). Programa Genes-Aplicativo computacional em genética e estatística. Retrieved April 11, 2019, from http://www.ufv.br/dbg/genes/genes.htm

Cruz, I. A. (1999). Lagarta-do-cartucho: enfrente o principal inimigo do milho. Revista Cultivar, 21, 1-68.

Farias, J. R., Andow, D. A., Horiksoshi, R. J., Sorgatto, R. J., Fresia, P., Santos, A. C., \& Omoto, C. (2014). Field-evolved resistance to Cry1F crop by Spodoptera frugiperda (Lepidoptera: Noctuidae) in Brazil. Crop Protection, 64, 150-158. https://doi.org/10.1016/j.cropro.2014.06.019 
Gobbi, P. C., Machado, L. L., Abreu, J. A., Carvalho, I. F., \& Afonso-Rosa, A. P. S. (2017). Eficiência de controle de populações de Spodoptera frugiperda (Smith, 1797) com inseticidas. 62 ${ }^{a}$ Reunião Técnica Anual da Pesquisa do Milho e $45^{a}$ Reunião Técnica Anual da Pesquisa do Sorgo, 62, 91-94.

Hellwig, L., Grutzmacher, A. D., Santos, P. M., Trecha, C. O., Medina, L. B., Berto, R. M., \& Rosa, A. P. S. A. (2017). Efeito do aumento da densidade de larvas de Spodoptera frugiperda em milho convencional em casa de vegetação. Revista Brasileira de Milho e Sorgo, 16, 337-350. https://doi.org/10.18512/ 1980-6477/rbms.v16n3p337-350

Huang, F., Qureshi, J. A., Meagher-Junior, R. L., Reisig, D. D., Head, G. P., Andow, D. A., ... Dangal, V. (2014). Cry1F resistance in fall armyworm Spodoptera frugiperda: Single gene versus pyramided $B t$ crop. PLoS ONE, 9, 1-10. https://doi.org/10.1371/journal.pone.0112958

IRGA (Instituto Rio Grandense do Arroz). (2019). Retrieved April 11, 2019, from http://irga.rs.gov.br/ upload/20141126093631seminario_arroz_vermelho_2013 anais[1].pdf

Jurat-Fuentes, J. L., \& Crickmore, N. (2017). Specificity determinants for Cry insecticidal proteins: Insights from their mode of action. Journal of Invertebrate Pathology, 142, 5-10. https://doi.org/10.1016/j.jip. 2016.07.018

Lima-Junior, I. S., Degrande, P. E., Melo, E. P., Bertoncello, T. F., \& Suekane, R. (2012). Infestação de Spodoptera frugiperda (J. E. Smith, 1797) (Lepidoptera: Noctuidae) e seus inimigos naturais em milho nas condições de sequeiro e irrigado. Revista Agrarian, 5, 14-19.

Melo, E. P., Degrande, P. E., Lima-Junior, I. S., Suekane, R., Kodama, C., \& Fernandes, M. G. (2014). Disposição espacial e injúrias da lagarta-do-cartucho Spodoptera frugiperda (J. E. Smith) (Lepidoptera: Noctuidae) em milho. Revista Ceres, 61, 343-349. https://doi.org/10.1590/S0034-737X2014000300007

Mendes, S. M., Boregas, K. G. B., Lopes, M. E., Waquil, M. S., \& Waquil, J. M. (2011). Respostas da lagarta-do-cartucho a milho geneticamente modificado expressando a toxina Cry 1A(b). Pesquisa Agropecuária Brasileira, 46, 239-244. https://doi.org/10.1590/S0100-204X2011000300003

Mendes, S. M., Marucci, R. C., Moreira, S. G., \& Waquil, J. M. (2008). Milho Bt: Avaliação preliminar da resistência de híbridos comerciais à lagarta do cartucho, Spodoptera frugiperda (J. E. Smith, 1797) (Comunicado Técnico 157, p. 8). Sete Lagoas: Embrapa Milho e Sorgo.

Miguel, F. B., Esperancini, M. S. T., \& Grizotto, R. K. (2014). Rentabilidade e risco da produção de milho safrinha geneticamente modificado e convencional na região de Guaíra/SP. Revista Energia na Agricultura, 29, 64-75. https://doi.org/10.17224/EnergAgric.2014v29n1p64-75

Miguel, F. B., Esperancini, M. S. T., Furlaneto, F. P. B., Bárbaro, I. M., \& Ticeli, M. (2013). Adoção de milho transgênico no estado de São Paulo: resultados econômicos e riscos. Informações Econômicas, 43, 5-13.

Moraes, A. R. A., Lourenção, A. L., \& Paterniani, M. E. A. G. Z. (2015). Resistência de híbridos de milho convencionais e isogênicos transgênicos a Spodoptera frugiperda (Lepidoptera: Noctuidae). Bragantia, 74, 50-57. https://doi.org/10.1590/1678-4499.0367

Omoto, C., Bernardi, D., Salmeron, E., \& Farias, J. R. (2013). Manejo de resistência de Spodoptera frugiperda a inseticidas e plantas Bt (p. 2). ESALQUE/USP, Piracicaba, Brazil.

Omoto, C., Bernardi, O., Salmeron, E., Sorgatto, R. J., Dourado, P. M., Crivellari, A., ... Head, G. P. (2016). Field-evolved resistance to Cry1AB crop by Spodoptera frugiperda in Brazil. Pest Management Science, 72, 1727-1736. https://doi.org/10.1002/ps.4201

Padilha, F. A., Resende, A. V., Moreira, S. G., Guimarães, L. J. M., Guimarães, P. E. O., \& Oliveira, A. C. (2015). Produtividade de híbridos de milho sob dois níveis de tecnologia na região central de minas gerais. Revista Brasileira de Milho e Sorgo, 14, 207-218. https://doi.org/10.18512/1980-6477/rbms.v14n2p207-218

Pashley, D. P., Pawar, C. S., \& Bhatnagar, V. S. (1987). Impact of fall armyworm (Lepidoptera: Noctuidae) host strains on the evaluation of bermuda grass resistance. Journal Economic Entomology, 80, 1127-1130. https://doi.org/10.1093/jee/80.6.1127

Pinto, L. F. S., Miguel, P., \& Pauletto, E. A. (2017). Solos de várzea e terras baixas. In B. M. Emygdio, A. P. S. A. Rosa, \& A. C. B. Oliveira (Eds), Cultivo de soja e milho em terras baixas do Rio Grande do Sul (pp. 23-43). Embrapa, Brasília, Brazil.

Polato, A. S., \& Oliveira, N. C. (2011). Eficiência do controle da lagarta-do-cartucho na cultura do milho em função de diferentes horários de aplicação de inseticida. Campo Digital, 6, 44-53. 
Porto, M. P., Silva, S. D. A., Winkler, E. I. G., Silva, C. A. S., \& Parfitt, J. M. B. (1998). Milho em várzeas de clima temperado na região sul do Brasil: Cultivares e manejo de solo e água (Circular Técnica 6, p. 31). Pelotas: Embrapa Clima Temperado.

Richetti, A. (2017). Viabilidade econômica da cultura do milho safrinha 2018, em Mato Grosso do Sul (Comunicado Técnico 231, p. 6). Dourados: Embrapa Agropecuária Oeste.

Santos, H. G., Jacomine, P. K. T., Anjos, L. H. C., Oliveira, V. A., Lumbreiras, J. F., Coelho, M. R., ... Oliveira, J. B. (2013). Sistema brasileiro de classificação de solos (p. 353). Embrapa, Brasília, Brazil.

Scorvo-Filho, J. D., Martin, N. B., \& Ayroza, L. M. S. (1998). Piscicultura em São Paulo: Custos e retornos de diferentes sistemas de produção na safra 1996/97. Informações Econômicas, 28, 41-62.

Shioga, O. S., Gerage, A. C., Araújo, P. M., Bianco, R., Custódio, A. A. P., \& Barros, A. S. R. (2016). Avaliação estadual de cultivares de milho safra 2015/2016 (Boletim Técnico 87, p. 68). Londrina: Instituto Agronômico do Paraná.

Shioga, O. S., Gerage, A. C., Araújo, P. M., Sera, G. H., \& Bianco, R. (2012). Avaliação estadual de cultivares de milho safra 2011/2012 (Boletim Técnico 77, p. 117). Londrina: Instituto Agronômico do Paraná.

Shioga, O. S., Gerage, A. C., Araújo, P. M., Sera, G. H., \& Bianco, R. (2015). Avaliação estadual de cultivares de milho segunda safra 2015 (Boletim Técnico 86, p. 103). Londrina: Instituto Agronômico do Paraná.

Silva, P. R. A., Correia, T. P. S., Sousa, S. F. G., \& Millani, T. M. (2015). Economic analysis of conventional and transgenic corn under two soil tillage systems. Engenharia Agricola, 35, 1032-1041. https://doi.org/ 10.1590/1809-4430-Eng.Agric.v35n6p1032-1041/2015

SPGG (Secretaria de Planejamento, Governança e Gestão do Rio Grande do Sul). (2019). Retrieved April 11, 2019, from http://www.atlassocioeconomico.rs.gov.br/milho

Storer, N. P., Babcock, J. M., Schlenz, M., Meade, T., Thompson, G. D., Bing, J. W., \& Huckaba, R. M. (2010). Discovery and characterization of field resistance to Bt crop: Spodoptera frugiperda (Lepidoptera: Noctuidae) in Puerto Rico. Journal Economic Entomology, 103, 1031-1038. https://doi.org/10.1603/ EC10040

Trindade, R. B. B., Fernandes, M. G., Oliveira, A. C., \& Martins, P. H. A. (2017). Distribuição espacial de Spodoptera frugiperda (J. E. Smith) (Lepidoptera, noctuidae) em milho convencional e Bt. EntomoBrasilis, 10, 89-93. https://doi.org/10.12741/ebrasilis.v10i2.683

Viana, G., Faria, G., \& Bairros, T. (2016). Irregularidade de chuva prejudica produção de milho em Mato Grosso (p. 6). Embrapa, Brasília, Brazil.

Wangen, D. R. B., Pereira-Junior, P. H. S., \& Santana, W. S. (2015). Controle de Spodoptera frugiperda (J. E. Smith, 1797) na cultura do milho com inseticidas de diferentes grupos químicos. Enciclopédia Biosfera, 11, 801-808. https://doi.org/10.18677/Enciclopedia_Biosfera_2015_119

Waquil, J. M., Vilela, F. M. F., \& Foster, J. E. (2002). Resistência do milho (Zea mays L.) transgênico (Bt) à lagarta-do-cartucho, Spodoptera frugiperda (Smith) (Lepidoptera: Noctuidae). Revista Brasileira de Milho e Sorgo, 1, 1-11. https://doi.org/10.18512/1980-6477/rbms.v1n3p1-11

\section{Copyrights}

Copyright for this article is retained by the author(s), with first publication rights granted to the journal.

This is an open-access article distributed under the terms and conditions of the Creative Commons Attribution license (http://creativecommons.org/licenses/by/4.0/). 